\title{
DIAGNOSIS DAN PENATALAKSANAAN HEMOROID
}

\author{
Kadek Helen Yustika Pradiantini ${ }^{1}$, I Gede Surya Dinata ${ }^{2}$ \\ ${ }^{1}$ Prodi Kedokteran, Universitas Pendidikan Ganesha \\ ${ }^{2}$ Prodi Kedokteran, Universitas Pendidikan Ganesha \\ e-mail: helen.yustika@undiksha.ac.id, surya.dinata@undiksha.ac.id
}

\begin{abstract}
Abstrak
Hemoroid merupakan jaringan normal yang terdapat pada semua orang. Hemoroid terdiri dari pleksus arteri-vena yang berfungsi sebagai katup dalam saluran anus untuk membantu sistem sfingter anus, mencegah inkontinensia flatus dan cairan. Bila hemoroid menyebabkan suatu keluhan seperti rasa tidak nyaman, gatal pada anus atau bahkan perdarahan lewat anus, maka perlu diperhatikan dan ditangani lebih lanjut. Hemoroid dapat diklasifikasikan menjadi hemoroid interna dan hemoroid eksterna. Penyebab dari hemoroid belum diketahui secara pasti, tetapi ada hal-hal paling umum yang diduga dapat memicu terjadinya hemoroid, yaitu, mengejan terlalu keras saat proses defekasi, kehamilan, asites dan faktor usia. Untuk menegakkan diagnosis hemoroid dibutuhkan pemeriksaan penunjang yang mendukung. Hemoroid merupakan kondisi yang sangat umum dan mempengaruhi sekitar 10 juta orang per tahun. Satu studi memperkirakan bahwa lebih dari $50 \%$ populasi AS yang berusia di atas 50 tahun memiliki pengalaman tentang penyakit hemoroid. Dari beberapa penelitian yang dilakukan, orang yang lebih sering menderita hemoroid berjenis kelamin laki-laki dan puncak terjadinya hemoroid berada pada usia 35 sampai 65 tahun dan jarang terjadi pada usia dibawah 20 tahun. Meskipun hemoroid tidak mengancam jiwa, tetapi penyakit ini sangat berpotensi mengurangi kualitas hidup seseorang. Tatalaksana untuk hemoroid tergantung dari derajat keparahan hemoroid itu sendiri. Terapi untuk hemoroid dapat berupa terapi konservatif, terapi non bedah dan terapi bedah.
\end{abstract}

Kata kunci: Hemoroid, Gejala, Klasifikasi, Tatalaksana.

\begin{abstract}
Hemorrhoids are normal tissue that can be found in all people. Hemorrhoids consist of arterial-venous plexuses which function as valves in the anal canal to help the anal canal sphincter system prevent flatus and fluid incontinence. If hemorrhoids cause a complaint such as discomfort, itching of the anus, or even anal bleeding, it needs to be considered and treated further. Hemorrhoids can be classified into internal hemorrhoids and external hemorrhoids. The cause of hemorrhoids is not yet known with certainty, but there are things that are most commonly thought to trigger hemorrhoids, namely, straining too hard during defecation, pregnancy, ascites and age. To make a diagnosis of hemorrhoids is needed supporting investigations. Hemorrhoids are a very common condition and affect about 10 million people per year. One study estimates that more than $50 \%$ of the US population over the age of 50 years have experience of hemorrhoidal disease. From several studies conducted, people who more often suffer hemorrhoids is male sex and the peak occurrence of hemorrhoids occurs at the age of
\end{abstract}

GMJ $\mid 38$ 
35 to 65 years and rarely occurs at the age of under 20 years. Although hemorrhoids are not life-threatening, this disease has the potential to reduce one's quality of life. Treatment for hemorrhoids depends on severity of hemorrhoids. Treatment for hemorrhoids is divided into conservative therapy, non-surgical therapy and surgical therapy.

Keywords : Hemorrhoids, Symptoms, Classification, Treatment.

\section{PENDAHULUAN}

Rektum merupakan bagian paling ujung dari usus besar yang berbentuk lurus (setelah kolon sigmoid) dan berakhir di anus. Rektum dibatasi oleh mukosa epitel kolumnar yang dipersarafi oleh sistem saraf simpatis dan parasimpatis yang mengakibatkan rektum kurang sensitif. Pasokan pembuluh darah dan limfatiknya berasal dari sistem hipogastrik (Ganz, 2013). Rektum memiliki ukuran sepanjang $12 \mathrm{~cm}$ dan berfungsi penting dalam defekasi (proses pengeluaran kotoran dalam tubuh) karena ketika kolon mendorong feses ke dalam rektum, peregangan yang terjadi di rektum merangsang reseptor regang di dinding rektum, memicu refleks defekasi dan timbul keinginan untuk buang air besar, atau rektum juga bisa disebut sebagai tempat penyimpanan feses sementara (Sherwood, 2019).

Anus memiliki ukuran sepanjang 3-4 cm dan dilapisi oleh anoderm. Anoderm merupakan epitel skuamosa yang dimodifikasi dan sensitif yang dipersarafi oleh saraf sensorik somatik dan dipasok oleh nervus hemoroid inferior (Ganz, 2013). Anus berperan sebagai saluran untuk mengeluarkan feses dari dalam tubuh saat defekasi. Proses defekasi ini dipengaruhi oleh sistem saraf dan otot. Otot yang paling berperan adalah otot sfingter. (Sherwood, 2019).

Hemoroid merupakan jaringan normal yang dimiliki oleh semua orang. Hemoroid terdiri dari pleksus arterivena yang berfungsi sebagai katup di dalam saluran anus untuk membantu sistem sfingter anus, mencegah inkontinensia flatus dan cairan (Sjamsuhidajat, 2016). Apabila hemoroid mengalami pelebaran dan inflamasi maka akan ditandai dengan perdarahan dan prolaps pada bantalan anal kanal yang mengakibatkan perubahan struktur anatomi, perubahan fisiologis, dan manifestasi klinis dari perubahan tersebut yang memerlukan penanganan lebih lanjut (Lalisang, 2016).

Hemoroid merupakan pelebaran dan inflamasi pembuluh darah vena di anus dari pleksus hemoroidalis. Hemoroid dibedakan menjadi dua bagian yaitu hemoroid eksterna dan hemoroid interna berdasarkan letaknya dari garis mukokutan (garis dentata). Hemoroid eksterna timbul dari pelebaran dan inflamasi vena subkutan (di bawah kulit) di bawah atau di luar garis dentate dan hemoroid interna timbul dari dilatasi vena submukosa (di bawah mukosa) di atas garis dentata (Sudarsono, 2015).

GMJ | 39 


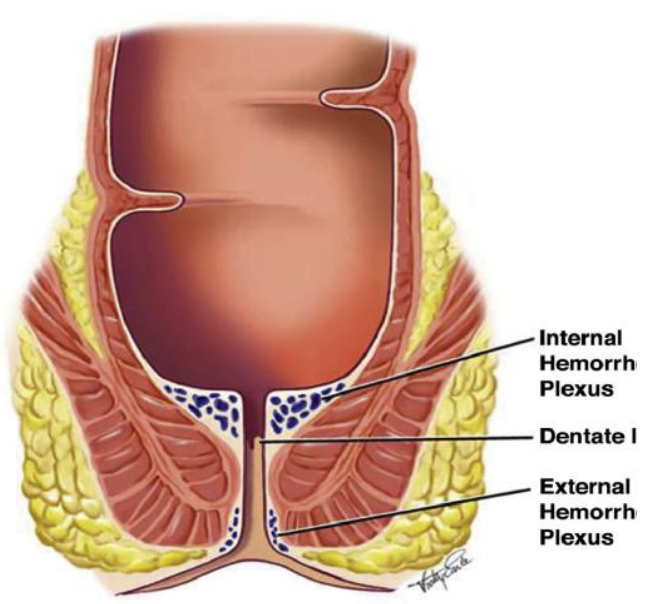

Gambar 1. Anorektum dengan hemoroid interna dan hemoroid eksterna (Sandler \& Peery, 2019)

Etiologi hemoroid tidak dapat dipastikan. Sejak diteliti oleh Burkitt dan Graham-Stewart pada tahun 1970-an, hemoroid dianggap disebabkan oleh diet rendah serat dan konstipasi (sembelit). Keyakinan saat ini adalah bahwa konstipasi kronis dan feses yang keras dapat mengakibatkan degenerasi jaringan pendukung di saluran anus dan pergeseran dari bantalan anal kanal (Sandler \& Peery, 2019). Mengejan yang terlalu lama, kehamilan dan asites juga dapat berkontribusi terhadap dilatasi, pembengkakan, dan prolaps jaringan pembuluh darah hemoroid (Mounsey, Halladay \& Sadiq, 2011). Peningkatan tekanan intra abdomen karena tumor, usia tua, hubungan seksual peranal, kurang minum air, kurang olahraga/imobilisasi diyakini juga sebagai faktor risiko terjadinya hemoroid. Meskipun hemoroid tidak mengancam jiwa, tetapi penyakit ini sangat berpotensi mengurangi kualitas hidup seseorang (Septadina \& Veronica, 2015).
Hemoroid merupakan kondisi yang sangat umum dan mempengaruhi sekitar 10 juta orang per tahun. Satu studi memperkirakan bahwa lebih dari $50 \%$ populasi AS yang berusia di atas 50 tahun memiliki pengalaman tentang penyakit hemoroid (Foxx-Orenstein, 2014). Hemoroid sebelum usia 20 tahun jarang terjadi namun, tidak menutup kemungkinan untuk terjadi. Orang kulit putih dan status sosial ekonomi yang lebih tinggi lebih sering terkena dampak daripada orang kulit hitam dan orang yang status sosial ekonomi rendah. Namun, hubungan ini mungkin mencerminkan perbedaan dalam perilaku pencarian kesehatan daripada prevalensi yang sebenarnya. Di Inggris, hemoroid dilaporkan mempengaruhi $13 \%-36 \%$ dari populasi umum. Namun, estimasi ini mungkin lebih tinggi daripada prevalensi yang sebenarnya karena studi berbasis komunitas terutama mengandalkan laporan diri dan pasien dapat menghubungkan gejala anorektal dengan hemoroid (Lohsiriwat, 2012).

Penelitian yang dilakukan di RSUP Dr. Mohammad Hoesin Palembang tahun 2009 hingga 2013 yang memenuhi kriteria inklusi didapatkan sampel yang mengalami hemoroid dimulai dari usia 15 tahun dan mengalami peningkatan seiring pertambahan usia serta mencapai puncak pada usia 39-46 tahun $(27,84 \%)$, lalu mengalami penurunan secara bertahap mulai dari usia 63 tahun. Pada penelitian ini, usia tertua penderita hemoroid adalah 78 tahun. Hasil penelitian ini sesuai dengan teori yang menyatakan bahwa orang dewasa mengalami hemoroid dengan insiden puncak antara usia 45 hingga 65 tahun.

GMJ | 40 
Hasil penelitian ini juga sesuai dengan penelitian yang dilakukan oleh Nugroho bahwa persentase hemoroid sangat kecil ditemukan pada usia kurang 20-30 tahun (Septadina \& Veronica, 2015).

Penelitian yang dilakukan di RSUP Haji Adam Malik Medan pada periode 2009 hingga 2011 didapatkan 95 dari 166 pasien hemoroid berjenis kelamin laki-laki (Utomo, 2009-2013). Pada penelitian epidemiologi yang dilakukan di Osijek, Kroasia tahun 2018 yang melibatkan 46 peserta dari kedua jenis kelamin, usia rata-rata $23-80$ tahun, yang menderita gejala hemoroid internal derajat I dan II (perdarahan, prolaps, nyeri, dan gatal-gatal). Di antara mereka, ada 24/46 laki-laki $(52,2 \%)$ dan $22 / 46$ perempuan $(47,8 \%)$. Menurut derajat hemoroid interna yang mereka derita, ada 23/46 (50,0\%) peserta dengan hemoroid interna derajat I dan 23/46 (50,0\%) peserta dengan hemoroid interna derajat II. Menurut ada atau tidak adanya riwayat keluarga dengan hemoroid, ada 27/46 $(58,7 \%)$ peserta dengan riwayat keluarga positif hemoroid dan 19/46 $(41,3 \%)$ peserta dengan riwayat keluarga negatif hemoroid (Miškulin dkk, 2018).

\section{HASIL DAN PEMBAHASAN}

Gejala dari hemoroid yang paling umum adalah pendarahan di anus dan keluhan yang paling utama adalah ditemukannya massa atau tonjolan di daerah anus (Song \& Kim, 2011).

Pada hemoroid interna, perdarahan merupakan gejala paling umum yang dilaporkan. Pendarahan ini biasanya disebabkan karena feses yang keras. Darah yang keluar berwarna merah segar dan tidak bercampur dengan feses, dapat hanya berupa garis pada feses atau kertas pembersih sampai pada pendarahan yang terlihat menetes atau mewarnai air toilet menjadi merah. Gejala lain yang sering muncul adalah sensasi prolaps jaringan. Hemoroid internal yang sudah mengalami prolaps dapat disertai inkontinensia fekal ringan, keluarnya lendir, sensasi kepenuhan perianal, dan iritasi kulit perianal yang dapat menimbulkan rasa gatal yang dikenal dengan pruritus anus dan disebabkan oleh kelembaban yang terus-menerus serta rangsangan mukus. Rasa nyeri lebih jarang terjadi dibandingkan dengan hemoroid eksterna (Sun \& Migaly, 2016).

Kadang perdarahan hemoroid berulang dapat menyebabkan anemia berat. Jika sudah muncul prolaps menetap dan tidak dapat didorong masuk lagi, biasanya disertai keluarnya mukus dan terdapatnya feses pada pakaian dalam (Sjamsuhidajat, 2016).

Hemoroid eksterna lebih cenderung dikaitkan dengan rasa sakit, karena aktivasi persarafan perianal yang diakibatkan oleh trombosis. Pasien biasanya menggambarkan massa perianal yang nyeri yang terasa lunak saat dipalpasi. Massa mungkin meningkat dalam ukuran dan keparahan dari waktu ke waktu. Pendarahan juga dapat terjadi jika ulserasi berkembang dari nekrosis hemoroid trombosis, dan darah ini cenderung lebih gelap dan lebih menggumpal daripada perdarahan dari hemoroid interna (Sun \& Migaly, 2016).

Pada patofisiologi hemoroid, ada beberapa faktor yang berperan penting dalam perkembangan hemoroid. Pertama, sifat mekaniknya. Setiap 
kelemahan jaringan pendukung dan ligamen pengikat bantalan anal kanal membuat bantalan anal kanal prolaps selama mengejan dengan buang air besar. Kebiasaan buang air besar dalam posisi duduk memainkan peran penting dalam perkembangan hemoroid, karena sumbu dubur diposisikan dengan beban terfokus pada anus. Selanjutnya, bantalan anal kanal prolaps seperti itu tidak dapat dikurangi secara spontan, tetapi secara manual (Lalisang, 2016).

Kedua yaitu, hemodinamik. Aliran

balik vena karena tersumbatnya anastomosis dari arteriovenous yang menyebabkan pembengkakan dan penebalan serta memperbesar bantalan anal kanal, membiarkannya prolaps yang tidak dapat dikurangi karena ada penjepit sfingter anal yang ketat. Faktor-faktor ini ditemukan sesuai dengan satu dominan. Hemoroid internal ditemukan sebagai kombinasi dari buang air besar dengan feses yang keras dan kerusakan bantalan anal kanal yang merupakan semacam degenerasi jaringan pendukung. Kerusakan seperti itu membuat aliran darah pada pleksus hemoroidalis mengalami stagnasi (tidak lancar) dan edema lebih lanjut menyebabkan bantalan anal kanal yang membesar. Suatu kondisi yang membuat bantalan anal kanal mengalami prolaps secara permanen atau bermanifestasi sebagai perdarahan anus karena area tersebut diketahui rentan bermasalah. Statis aliran vaskuler menyebabkan marginalisasi leukosit yang kemudian melekat pada endotelium dan diikuti oleh pelepasan mediator inflamasi seperti prostaglandin dan radikal bebas, peningkatan permeabilitas kapiler, kerapuhan endotel, dan nekrosis dari dinding pembuluh darah (Lalisang, 2016).

Patogenesis hemoroid dikatakan multifaktorial. Banyak faktor yang mempengaruhi seperti pola makan dan kebiasaan diet, tonisitas sfingter anal, massa feses keras, mengejan, gestasi dan toileting dalam posisi duduk. Faktor-faktor ini menyebabkan gangguan aliran balik diikuti oleh edema dan tonjolan bantalan anal kanal, penurunan tonus sfingter yang memperburuk prolaps bantalan anal kanal yang dimanifestasikan dalam benjolan dan atau perdarahan anus (Lalisang, 2016).

Hemoroid dapat diklasifikasikan menjadi hemoroid interna dan hemoroid eksterna. Hemoroid interna adalah pembengkakan vena pada pleksus hemoroidalis superior, di atas linea dentate dan tertutup oleh mukosa. Hemoroid interna dapat dikelompokkan dalam empat derajat. Pada derajat pertama, hemoroid menyebabkan perdarahan merah segar tanpa nyeri pada waktu defekasi. Pada stadium awal seperti ini tidak terdapat prolaps. Pada derajat kedua, hemoroid menonjol melalui kanalis analis pada saat mengedan ringan tetapi dapat masuk kembali secara spontan. Pada derajat ketiga, hemoroid menonjol saat mengejan dan harus didorong masuk secara manual sesudah defekasi. Dan pada derajat keempat, hemoroid yang menonjol keluar dan tidak dapat dapat didorong masuk kembali (Lohsiriwat, 2015).

Hemoroid eksterna adalah terjadinya varises pada pleksus hemoroidalis inferior dibawah linea dentate dan tertutup oleh kulit. 
Hemoroid ini diklasifikasikan sebagai akut dan kronik. Bentuk akut berupa pembengkakan bulat kebiruan pada tepi anus dan sebenarnya merupakan hematoma. Walaupun disebut hemoroid trombosis eksterna akut, bentuk ini sangat nyeri dan gatal karena ujung-ujung saraf pada kulit merupakan reseptor nyeri. Hemoroid eksterna kronik berupa satu atau lebih lipatan kulit anus yang terdiri dari jaringan dan sedikit pembuluh darah (Sudarsono, 2015).

Terdapat beberapa diagnosis banding untuk hemoroid seperti, karsinoma kolorektum, penyakit divertikel, polip dan kolitis ulserosa, karena memiliki manifestasi klinis yang sama dengan gejala yang paling sering terjadi di kasus hemoroid yaitu pendarahan pada rektum (Sjamsuhidajat, 2016).

Untuk menegakkan diagnosis untuk penyakit hemoroid diperlukan pemeriksaan penunjang untuk membantu untuk menyingkirkan kemungkinan dari diagnosis banding. Pada pemeriksaan colok dubur, hemoroid interna tidak dapat diraba sebab tekanan vena di dalamnya tidak cukup tinggi dan biasanya tidak nyeri jika derajat hemoroid masih dalam tahap awal, tetapi pemeriksaan colok dubur diperlukan untuk menyingkirkan kemungkinan karsinoma rektum (Sjamsuhidajat, 2016).

Pasien dengan umur dibawah 50 tahun yang memiliki resiko rendah terkena hemoroid, dapat dilakukan pemeriksaan fleksibel sigmoidoskopi yang terbukti sebagai pemeriksaan awal yang tepat (Trompetto $d k k, 2015)$.

Kolonoskopi wajib dilakukan pada pasien yang lebih tua dan memiliki sejarah neoplasma kolorektal baik pribadi maupun keluarga, penyakit radang usus, perubahan kebiasaan buang air besar, penurunan berat badan yang signifikan baru-baru ini, dan pada pemeriksaan laboratorium ditemukan anemia defisiensi besi (Trompetto $d k k, 2015)$.

Pemeriksaan dengan anoskopi diperlukan untuk melihat hemoroid interna yang tidak menonjol keluar. Anoskop dimasukkan dan diputar untuk mengamati keempat kuadran. Hemoroid interna terlihat sebagai struktur vascular yang menonjol ke dalam lumen. Apabila penderita diminta mengejan sedikit, ukuran hemoroid akan membesar dan penonjolan atau prolaps akan lebih nyata (Sjamsuhidajat, 2016).

Proktosigmoidoskopi perlu dikerjakan untuk memastikan bahwa keluhan bukan disebabkan oleh proses radang atau proses keganasan di tingkat yang lebih tinggi (Sjamsuhidajat, 2016).

Endosonografi anorektal biasanya tidak dilakukan untuk diagnosis penyakit hemoroid, tetapi dapat bermanfaat untuk menentukan apakah hemoroid berhubungan dengan penebalan jaringan submukosa dan sfingter anal internal dan eksternal (Trompetto $d k k$, 2015).

Penatalaksanaan untuk hemoroid tergantung dari derajat keparahan hemoroid itu sendiri. Penatalaksanaan hemoroid dibagi menjadi terapi nonbedah dan terapi bedah. Pilihan spesifik perawatan tergantung pada usia pasien, keparahan gejala, dan komorbiditas (Sun \& Migaly, 2016). Terapi konservatif seperti modifikasi gaya hidup dan diet adalah perawatan 
medis andalan untuk terapi konservatif penyakit hemoroid yang termasuk dalam terapi non-bedah. Secara khusus, modifikasi gaya hidup harus mencakup peningkatan asupan cairan yang cukup, mengurangi konsumsi makanan berlemak dan pedas, menghindari tegang, dan olahraga teratur. Rekomendasi diet harus mencakup peningkatan asupan serat dan menghindari mengejan terlalu keras atau berlebihan saat defekasi (Sun \& Migaly, 2016).

Terdapat sejumlah metode yang tidak melibatkan eksisi bedah tersedia untuk mengobati pasien dengan hemoroid. Prosedur ini biasanya dilakukan di ruangan dokter dan tidak memerlukan anestesi (Gami, 2011). Seperti yang dinyatakan oleh ACRCS, ada 3 tujuan utama dari dilakukannya terapi hemoroid tanpa tindakan bedah yaitu, pertama untuk mengurangi vaskularisasi hemoroid, kedua untuk mengurangi jaringan yang berlebihan, dan ketiga untuk memfiksasi hemoroid ke dinding rektum untuk mengurangi dan memperbaiki prolaps (Ganz, 2013).

Terapinya berupa ligasi dengan gelang karet, skleroterapi, krioterapi atau bedah beku dan koagulasi inframerah adalah prosedur yang paling umum tetapi tidak ada konsensus tentang perawatan yang optimal (Sun \& Migaly, 2016).

Ligasi dengan gelang karet biasanya digunakan untuk mengobati hemoroid interna derajat II dan III. Dengan bantuan anuskop, mukosa di atas hemoroid yang menonjol dijepit dan ditarik atau dihisap ke dalam tabung ligator khusus. Gelang karet didorong dari ligator dan ditempatkan dengan rapat di sekeliling mukosa pleksus hemoroidalis tersebut. Nekrosis karena iskemia terjadi dalam beberapa hari. Mukosa bersama karet akan lepas sendiri. Fibrosis dan jaringan parut akan terjadi pada pangkal hemoroid tersebut. Pada satu kali terapi hanya diikat satu kompleks hemoroid, sedangkan ligasi berikutnya dilakukan dalam jarak waktu dua sampai empat minggu (Sjamsuhidajat, 2016). Penyembuhan total terjadi beberapa minggu kemudian. Komplikasi sangat jarang, tetapi yang mungkin terjadi adalah rasa sakit, retensi urin, perdarahan tertunda, dan sepsis perineum yang sangat jarang terjadi (Sun \& Migaly, 2016).

Skleroterapi biasanya digunakan untuk pasien dengan hemoroid interna derajat I dan II. Seperti ligasi gelang karet, skleroterapi tidak memerlukan anestesi lokal. Dilakukan melalui anoskop, hemoroid internal ditemukan dan disuntikkan larutan kimia yang merangsang misalnya $5 \%$ fenol dalam minyak nabati ke dalam submukosa. Selanjutnya akan menyebabkan fibrosis, fiksasi ke saluran anus, dan akhirnya obliterasi jaringan hemoroid yang redundan. Komplikasi skleroterapi termasuk ketidaknyamanan kecil atau berdarah. Namun, fistula dubur atau perforasi bisa sangat jarang terjadi karena suntikan yang salah tempat (Sun \& Migaly, 2016).

Krioterapi atau bedah beku adalah tindakan dengan membekukan hemoroid pada suhu yang sangat rendah. Krioterapi atau bedah beku ini tidak dipakai secara luas karena mukosa yang nekrotik sukar ditentukan luasnya. Krioterapi atau bedah beku ini lebih cocok untuk terapi paliatif 
karsinoma rektum yang inoperable (Sjamsuhidajat, 2016).

Koagulasi inframerah dilakukan dengan memfokuskan radiasi inframerah dari lampu tungstenhalogen melalui ujung probe polimer ke pangkal hemoroid. Ini menciptakan tukak yang kemudian sembuh, menghasilkan cicatrisation (jaringan parut) yang mengurangi aliran darah ke hemoroid. Prosedur ini ditoleransi dengan baik, tetapi tingkat keberhasilannya lebih rendah dari ligasi dengan gelang karet. Koagulasi yang tidak seimbang dapat dipertimbangkan pada pasien yang menggunakan terapi antikoagulan (Mounsey, Halladay \& Sadiq, 2011).

Selanjutnya ada pula terapi hemoroid dengan tindakan bedah. Terapi dengan tindakan bedah ini biasanya digunakan untuk hemoroid interna yang sudah cukup parah atau bahkan sudah mencapai derajat IV dan sangat mengganggu aktivitas pasien. Terapi bedah yang sering digunakan untuk hemoroid adalah hemoroidektomi eksisi, stapled hemorrhoidopexy dan Hemorrhoidal artery ligation (HAL) yang dikombinasikan dengan recto-anal repair (RAR).

Pada hemoroidektomi eksisi, sayatan elips dibuat di atas kompleks hemoroid, yang kemudian dimobilisasi dari sphincter yang mendasarinya dan dikeluarkan. Luka ditutup dengan jahitan. Dalam sebuah penelitian menunjukkan bahwa hemoroidektomi eksisi adalah pengobatan yang paling tepat untuk hemoroid interna derajat III dan IV dan hemoroid yang berulang ketika perawatan lain tidak efektif. Komplikasi pasca operasi hemoroidektomi eksisi lainnya termasuk skin tag, abses, fistula, dan kebocoran anal (Mounsey, Halladay \& Sadiq, 2011).

Stapled

hemorrhoidopexy merupakan terapi alternatif untuk hemoroid derajat II sampai IV. Alat yang digunakan akan menghilangkan kolom melingkar mukosa dan submukosa tepat di atas hemoroid, sehingga mengganggu pasokan darah. Cincin staples memperbaiki bantal vaskular yang dipindahkan ke bawah kembali ke lokasi semula untuk mengembalikan anatomi dan fungsi. Pasca operasi, pasien memiliki garis staples melingkar di atas garis dentata, yang akan terkubur di dalam mukosa dari waktu ke waktu. Staples dapat dicatat dalam rektum selama berbulanbulan setelah prosedur dan dapat menyebabkan perdarahan rektum. Dibandingkan dengan hemoroidektomi eksisi, stapled hemorrhoidopexy lebih baik dalam hal rasa sakit pasca operasi, waktu sampai kembali bekerja, dan komplikasi pruritus dan urgensi tinja (Mounsey, Halladay \& Sadiq, 2011).

Dan yang terakhir adalah HALRAR. Hemorrhoidal artery ligation (HAL) yang dikombinasikan dengan recto-anal repair (RAR) merupakan teknik alternatif untuk pengobatan hemoroid derajat I sampai derajat IV. Dengan hasil awal yang menjanjikan, skor nyeri lebih rendah daripada hemoroidektomi, dengan prosedur invasif minimal. HAL-RAR melibatkan anoscope dengan Doppler untuk mengidentifikasi posisi dan kedalaman arteri rektal, yang dapat diikat secara selektif 3-4 cm di atas garis dentate. Teknik ini telah diusulkan karena praktis, mudah dipelajari, invasif 
minimal, dan aman (Pusparani \& Purnomo, 2019).

\section{KESIMPULAN}

Hemoroid merupakan jaringan normal yang dimiliki oleh semua orang tetapi, bila hemoroid mengalami pelebaran dan inflamasi pada pembuluh darah vena di anus dari pleksus hemoroidalis akan menyebabkan ketidaknyamanan yang mengganggu. Meskipun hemoroid tidak mengancam jiwa, tetapi penyakit ini sangat berpotensi mengurangi kualitas hidup seseorang

Hemoroid dibagi menjadi dua yaitu hemoroid interna dan hemoroid eksterna. Hemoroid interna diklasifikasi menjadi derajat I, II, III dan IV, dan hemoroid eksterna dibagi berdasarkan sifatnya menjadi akut dan kronis. Hemoroid umumnya lebih sering terjadi pada orang dengan usia diatas 50 tahun tetapi tidak menutup kemungkinan dapat terjadi pada usia yang lebih muda.

Penyebab pasti dari hemoroid belum diketahui tapi banyak hipotesis yang menyebutkan bahwa mengejan berlebihan saat defekasi, penggunaan toilet duduk, kehamilan, asites, peningkatan tekanan intra abdomen karena adanya tumor, usia tua, hubungan seksual peranal, jarang berolahraga, kurang minum dan kurangnya konsumsi makanan berserat diakui dapat memicu terjadinya hemoroid. Dan menurut beberapa penelitian yang telah dilakukan, hemoroid cenderung lebih sering terjadi pada laki-laki. Insiden terjadinya hemoroid paling banyak pada usia 4565 tahun.
Diagnosis banding untuk hemoroid yaitu karsinoma kolorektum, penyakit divertikel, polip dan kolitis ulserosa. Untuk menegakkan diagnosis dapat dilakukan pemeriksaan penunjang seperti colok dubur, fleksibel sigmoidoskopi, kolonoskopi, anoskopi, proktosigmoidoskopi dan endosonografi anorektal.

Penatalaksanaan hemoroid dapat berupa terapi konservatif, terapi nonbedah dan terapi bedah yang disesuaikan dengan derajat dari keparahan hemoroid itu sendiri. Pilihan spesifik perawatan tergantung pada usia pasien, keparahan gejala, dan komorbiditas.

\section{DAFTAR PUSTAKA}

Danar Fahmi Sudarsono. (2015). Diagnosis Dan Penanganan Hemoroid. J Majority, 4(6), 31-34.

Foxx-Orenstein, A. E., Umar, S. B., \& Crowell, M. D. (2014). Common anorectal disorders. Gastroenterology and Hepatology, 10(5), 294-301.

Gami, B. (2011). Academic Sciences. 3, 5-13.

Ganz, R. A. (2013). The evaluation and treatment of hemorrhoids: A guide for the gastroenterologist. Clinical Gastroenterology and Hepatology, 11(6), 593-603. https://doi.org/10 $.1016 /$ j.cgh.2012.12.020

Hill, C., \& Carolina, N. (2011). Copyright (C) 2011 American Academy of Family Physicians.). American Family Physician, 84(2), 204-210.

Lalisang, T. J. (2016). Hemorrhoid: Pathophysiology and Surgical Management Literature review. The New Ropanasuri Journal of 
Surgery, 1(1), 31-36. https://doi. org/10.7454/nrjs.v1i1.9

Lohsiriwat, V. (2012). Hemorrhoids: From basic pathophysiology to clinical management. World Journal of Gastroenterology, 18 (17), 2009-2017. https://doi.org/ 10.3748/wjg.v18.i17.2009

Lohsiriwat, V. (2015). Treatment of hemorrhoids: A coloproctologist's view. World Journal of Gastroenterology, 21(31), 92459252. https://doi.org/10.3748/wjg. v21.i31.9245

Miškulin, M., Lalić, Z., Dumić, A., Miškulin, I., Ličanin, M. M., \& Pavlović, N. (2018). New topical treatment of symptomatic internal hemorrhoids in a general practice setting. Journal of Health Sciences, 8(3), 148-153. https:// doi.org/10.17532/jhsci.2018.454

Pusparani, C. A., \& Purnomo, S. (2019). Hemorrhoid artery ligation and recto-anal repair treatment for hemorrhoid: a case series. Bali Medical Journal, 8(3), 550. https://doi.org/10.15562/bmj.v8i3.1 550

Sandler, R. S., \& Peery, A. F. (2019). Rethinking What We Know About Hemorrhoids. Clinical Gastroenterology and Hepatology, 17(1), 8-15. https://doi.org/10. 1016 /j.cgh.2018.03.020

Sherwood, L. (2018). Pertahanan Tubuh. Fisiologi manusia : dari sel ke sistem. Edisi 9. EGC : Jakarta.
Septadina, I. S., \& Veronica, F. (2015). Gambaran Histopatologi Epitel Transisional Kolorektal pada Pasien Hemoroid. Jurnal Kedokteran Dan Kesehatan, 2(1), 85-91. http://ejournal.unsri.ac.id/ index.php/jkk/article/view/2537

Sjamshuhidajat \& de jong. 2017. Buku Ajar Ilmu Bedah. Jakarta: EGC.

Song, S. G., \& Kim, S. H. (2011). Optimal treatment of symptomatic hemorrhoids. Journal of the Korean Society of Coloproctology, 27(6), 277-281. https://doi.org/10. 3393/jk sc.2011.27.6.277

Sun, Z., \& Migaly, J. (2016). Review of Hemorrhoid Disease: Presentation and Management. Clinics in Colon and Rectal Surgery, 29(1), 22-29. https://doi.org/10.1055/s-00351568144

Utomo, F. D. Hubungan antara Usia dan Jenis Kelamin terhadap Derajat Hemoroid Internal di RSUD dr. Soedarso Pontianak Tahun 2009-2013. Jurnal Mahasiswa PSPD FK Universitas Tanjungpura, 2(2).

Trompetto, M., Clerico, G., Cocorullo, G. F., Giordano, P., Marino, F., Martellucci, J., Milito, G., Mistrangelo, M., \& Ratto, C. (2015). Evaluation and management of hemorrhoids: Italian society of colorectal surgery (SICCR) consensus statement. Techniques in Coloproctology, 19(10), 567-575. https://doi.org/10 $.1007 / \mathrm{s} 1015$ 